PEACE AND PENANCE IN LATE MEDIEVAL ITALY 



\section{Peace and Penance in Late Medieval Italy}

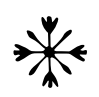

Katherine Ludwig Jansen 
Copyright (C) 2018 by Princeton University Press

Published by Princeton University Press,

41 William Street, Princeton, New Jersey o8540

In the United Kingdom: Princeton University Press,

6 Oxford Street, Woodstock, Oxfordshire OX20 1TR

press.princeton.edu

Jacket illustration: Workshop of Tederigo Memmi. Museum of Fine Arts, Boston.

Sarah Wyman Whitman Fund. Photograph (C) 2018 Museum of Fine Arts, Boston.

All Rights Reserved

Library of Congress Cataloging-in-Publication Data

Names: Jansen, Katherine Ludwig, 1957-author.

Title: Peace and penance in late medieval Italy / Katherine Ludwig Jansen.

Description: Princeton : Princeton University Press, 2017. | Includes bibliographical references and index.

Identifiers: LCCN 2017035263 | ISBN 9780691177748 (hardcover : alk. paper)

Subjects: LCSH: Penance-History. | Peace of mind-Religious

aspects-Christianity-History. | Peace-Religious

aspects-Christianity-History. | Reconciliation-Religious

aspects-Christianity-History. | Church history-Middle Ages, 6oo-150o. |

Italy-Church history.

Classification: LCC BV840 .J 362017 | DDC 282/.450902-dc23 LC record available at

https://lccn.loc.gov/2017035263

British Library Cataloging-in-Publication Data is available

This book has been composed in Miller Text

Printed on acid-free paper. $\infty$

Printed in the United States of America

10987654321 
In memory of

Janine Lowell Ludwig (1934-2012)

and

Fernanda De Vita (1911-2014) 
